\title{
ARE NEW RELIGIOUS MOVEMENTS NEW SOCIAL MOVEMENTS ?
}

James A Beckford

\section{Introduction}

I have been complaining for some years about the isolation and insulation of the sociology of religion (Beckford 1985a; 1989a). It tends to operate with its own special vocabulary and problematics which are not shared with other sociological specialisms. As a result, sociologists of religion have made few attempts to understand religion by means of the theories and concepts which are applied to other social phenomena. This is why I am enthusiastic about trying to locate research on new religious movements (NRMs) in the context of current theorizing about new social movements (NSMs). There are many parallels between the two types of movement, so let's see whether it's worthwhile to explain them both in similar terms.

The intention is not to reduce one category to the other. The main aim is simply to ask whether our understanding of NRMs would benefit from a comparison with NSMs, and vice versa. Broader questions about the comparability of the types of theory which have tried to explain the movements will also be raised in passing.

My conclusion will argue (a) that the similarities between NRMs and NSMs are superficial and coincidental, (b) that the two types of movement represent very different theoretical objects despite having similar designations, but (c) that there are good reasons for claiming that NSMs display religious or spiritual characteristics which are worthy of serious consideration.

Some definitions are in order at this point. Let me begin by emphasizing that there have frequently been new movements in many religions, just as social movements have been a feature of many societies and periods of history. Nevertheless, for reasons that will become clear later, it makes good sense to single out both the religious and social movements that emerged in the 1960s as 'new' in a distinctive way.

JA Beckford, from the Department of Sociology at the University of Warwick was visiting professor at the Department of Religious Studies, University of Stellenbosch during August and September 1993. 
For present purposes, the term 'NRM' has two referents. On the one hand, it refers to general shifts of religious sensibilities (e.g. the evangelical

movement in Latin America or the Islamic resurgence in many parts of the world); and, on the other, it refers to specific and deliberate mobilizations of people for relatively new religious purposes (e.g. the Jehovah's Witnesses movement worldwide or the Brotherhood of the Cross and Star movement in Nigeria).

It seems to me that a similar distinction between general and specific referents of 'NSM' is also appropriate'. On the one hand is the idea that very broad shifts are occurring at the level of values (e.g. from materialist to postmaterialist [Inglehart 1990] or from utilitarianism to creativity [Touraine 1985]); and on the other is the idea that deliberate mobilizations are occurring for the sake of specific objectives which imply increased freedom from reified rationality or exploitation by, for example, the promotion of human rights, equal opportunities for males and females, the abolition of nuclear weapons, or the creation of a safer natural environment.

There are undoubtedly close connections between the general and specific referents of both NRMs and NSMs. Indeed, much of the literature is concerned precisely with the theoretical articulations between these different levels of analysis. But I must add that the literature on NSMs is much more sophisticated in this respect. By contrast, sociologists of religion have tended to analyse specific NRMs in isolation from theories about general shifts in religious sensibilities. There is, in fact, a marked tendency to relegate discussions of NRMs to the status of an amusing and exotic sideshow in the sociology of religion. As a result, it is al too easy to dodge questions about the relationship between the dynamics of NRMs and mainstream religion. It is as if NRMs were not really religious and therefore not subject to the same general conditions as churches, synagogues and other longer-established religious organizations. Another implication is that the development of NRMs has no serious meaning for other religious organizations. What Richard Niebuhr called the adaptation of churches to the caste system of American society has been reflected among sociologists of religion in the form of a strong preference for studying the most formal expressions of religion.

I want to narrow the focus even further by confining the category of NRMs for my purposes to those movements which began to operate in many western countries in the $1950 \mathrm{~s}$ and $1960 \mathrm{~s}$ and which subsequently became controversial. The best known examples are the Unification Church ('the Moonies'), the International Society for Krisna Consciousness ('the Hare Krisnas') and Scientology. This relatively narrow focus enables us to discuss

1. The literature on NSMs is vast, but see in particular Bagguley, 1992; Boggs, 1986; Dalton \& Kuechler, 1990; Eyerman \& Jamison, 1990; Melucci, 1992; Scott, 1990; Touraine, 1985; Tucker, 1991. 
NRMs which developed at roughly the same time and in roughly the same countries as did specific NSMs such as the Campaign for Nuclear Disarmament (CND), Greenpeace, numerous feminist movements, animal rights groups, and urban social movements. Finally, it is worth noting that the late-1970s probably represented the high-water mark for both types of movement in terms of membership, publicity and material resources.

\section{New religious movements}

The first points to make about the controversial NRMs which emerged in the 1960 s are that they are numerous and very diverse. If we confine the scope to the USA alone (where the documentation is superior), we learn from the Institute for the Study of American Religion that about 800 'unconventional' religious groups are in existence (Melton 1987). Roughly 500 of them were founded between 1950 and 1988. A forthcoming bibliography on NRMs in the West will contain more than 8,000 items, 25 per cent of which relate tou the Unification Church -- probably the most controversial of the current NRMs (Saliba, 19). Sociological information about NRMs in Europe is scattered through numerous publications ${ }^{2}$. This literature shows that NRMs in Europe have been less numerous, less powerful but just as controversial as in the $\mathrm{USA}^{3}$ (where most of them originated).

Secondly, several schemes have been devised for reducing the diversity of NRMs to a manageable number of sub-types. For example, Wallis (1983) categorizes them on the basis of their ideologies into the three types of worldrejecting, world-accommodating and world-affirming. But my own preference is to categorize them according to their typical relations with the rest of society or, in other words, their mode of insertion in society (Beckford 1985b: 69-93). This divides NRMs into the three modes of refuge, revitalization, and release. The Hare Krisnas illustrate the refuge by trying to protect themselves from the impurities and illusions of the everyday world in monastic communities. The Moonies represent the revitalization mode by mobilizing themselves to infiltrate and change major social institutions or organizations. Scientology offers services to 'clients' who seek release of their inner potentials or release from psychological problems. It would take too long to elaborate on all the implications of this typology here, but I believe that each mode of insertion (or way of fitting into society) carries with

2. See Barker, 1982, 1989; Beckford, 1985b; Berger \& Hexel, 1981; Dyson \& Barker, 1988; Haack, 1979; Hardin, 1983; van der Lans \& Derks, 1983; Introvigne, 1989; Mat-Hasquin, 1982; Mayer, 1985, 1987; Vivien, 1985; Wallis, 1983; Wilson, 1990; Witteveen, 1984; Woodrow, 1977

3. A heated debate surrounds this issue. See Beckford \& Cole, 1988; Stark, 1985; Wallis, 1988. 
it a distinctive profile of members, forms of organization, economic possibilities, kinds of apostasy, and distinctive controversies.

Thirdly, and bearing in mind the diversity of NRMs, it is still possible to identify some of their common distinguishing characteristics. We shall then try to assess whether these features are sufficient distinctive to warrant keeping NRMs separate from the category of NSMs. In order to save time, I shall simply list the common characteristics as follows:-

1. Many NRMs have singular ideologies which draw upon exotic or unusual values and assumptions. They tend to offer immediate and practical routes to salvation.

2. The 'enrolment economies' of most NRMs are based on the recruitment of young, well educated, productive, healthy, middle-class adults.

3. There is a tendency for NRMs to aspire to total control over their participants' lives. They demand intense commitment and loyalty.

4. NRMs are 'greedy institutions' which experience a high rate of turnover in members and a strong sense of opposition from some apostates.

5. There is intense organized opposition to controversial NRMs.

6. The founder-leaders of NRMs tend to enjoy a high profile and autocratic powers.

7. A few NRMs have generated massive wealth.

8. The number of people directly affected by NRMs is very small. The cultural influence of the movements has also been slight. But their profile in the mass media is disproportionately alarmist and demonic.

\section{New social movements}

There can be little doubt, then, that NRMs represent relatively novel and distinctive ideologies, forms of membership, types of organization, and modes of public response. The question is whether their similarities with NSMs are purely superficial or coincidental. As we shall see, the fact that NRMs and NSMs arrived at roughly the same time, have similar social class bases, appeal mostly to young adults, focus on the alleged need for drastic cultural change, and are international in scope is not enough to suggest that they respond to the same circumstances or that they envisage the same sort of future. On the contrary, the salient characteristics of NSMs are so different that they call for separate explanation. I'il focus on four points here.

Again, the first point to make is that NSMs are diverse, although it is doubtful whether they are as numerous or as diverse as NRMs. I'm thinking primarily of the peace, ecology, human rights, animal rights, and feminist movements. Nevertheless, it seems clear that these movements share a common orientation towards breaking the cultural meanings of the system of 
social relations in which they operate. NSMs are less in the nature of demands for an improvement of material or political conditions and more like demands for a reinterpretation of the meaning of production and the orientation of society. In the words of Alberto Melucci (1985: 801), NSMs '... practice in the present the change they are struggling for: they redefine the meaning of social action for the whole society'. By comparison, many NRMs, especially those in the refuge and release modes, are content to redefine the cultural and social life of their members alone without seeking necessarily to reorient the whole society. Some NRMs thus tend to be segmental and deliberately marginal to mainstream society. Max Weber's category of world-rejection seems appropriate for some religious movements.

Second, NSMs are much less corporatist and 'greedy' than NRMs. They do not demand exclusive commitment and loyalty. According to Melucci, for example, NSMs aspire to build simultaneously personal individuation and communal identity. In fact, the very notion of 'membership' is alien to some NSMs because they seek a diffuse rather than segmental impact on society. Consequently, it is difficult to identify the boundaries of NSMs. This is mainly why Melucci (1989) now prefers to call them 'collective actions' in order to challenge the view of them as specific 'personnages'. They function mostly as submerged networks of sympathizers; and the overlaps between the networks are considerable. It follows that leaders tend to have a low profile and that formal organization is minimal. But, in order to avoid misunderstanding, let me make it clear that there undoubtedly are social movement organizations (SMOs) within these diffuse networks of sympathizers. Small groups of activists, some of whom may be very well organized, operate as modal points of connection between separate networks. They are often quite formal and long-lasting. Yet, the main point is that NSMs are much wider and more inclusive than these SMOs. The important thing is that the diffuse and the specific, the formal and the informal, or the lasting and the evanescent all coexist within Melucci's collection actions.

Third, the relatively low degree of corporateness and segmentalism among NSMs means that the controversies which surround them tend to focus less on concrete issues such as the alleged exploitation of members and more on the political and cultural challenges that they present to the status quo. Admittedly, there is public resistance to the message of some NSMs, and there is strong opposition to the direct action sometimes taken in the name of, for example, animal rights or pacifism. But in general there is a close association between the objectives of NSMs and issues on the public agenda of politics. The methods of pursuing these objectives also tend to be more conventional than do those employed by some NRMs.

Fourth, according to Claus Offe (1987) in particular, NSMs operate in the sphere of noninstitutional politics which lies outside the bounds of the institutions of liberal democracies and Welfare States. It is a condition of Offe's conceptualization that the movements' means of action should be 
legitimate and that their objectives should become binding for the whole community. This specifically excludes terrorism and what Offe calls 'new religious sects'. He excludes the latter largely because he has in mind only the movements in my 'refuge' category (see p4), that is, movements which seek escape from worldly illusion and error. But I doubt whether Offe is even aware of other types of NRMs which cannot be so conveniently omitted from consideration. Leaving this aside for the moment, he goes on to define the characteristic values of NSMs as autonomy, identity and opposition to manipulation. As a result, they allegedly deal with the external world by insisting on certain non-negotiable principles and thresholds. Again, it seems to me that this is precisely the stance of some NRMs in the 'revitalization' category. In short, while involvement in noninstitutional politics is certainly characteristic of NSMs, it is also shared by some NRMs as well. But Offe's analysis is too abstract to take account of this consideration. In short, NSMs tend to be concerned mainly with identity, values and meaning, to act like loose-knit networks, to attract relatively little organized opposition, and to operate outside formal political channels. It follows that NSMs typically consist of sympathizers and occasional supporters rather than strongly committed members. This also helps to make NSMs less controversial than the comparatively 'greedy' NRMs.

\section{The relationship between NRMs and NSMs}

The differences between NRMs and NSMs are so great that it would be a mistake to regard the former simply as instances of the latter. In fact, they are diametrically opposed to each other in some respects. Controversial NRMs are segmental, exclusive and totalizing, whereas NSMs tend to be diffuse, pluralistic and partial.

Moreover, the theoretical significance attributed to the two kinds of movements tends to be quite different. Sociologists of religion are disposed to consider NRMs as evidence of responses to anomie, secularization, the privatization of religion, and processes of rationalization. Durkheimian and Weberian problematics prevail. But the category of NSMs finds its strongest support in neo-marxist concerns with the tension between civil society and the capitalist state, the opposition between the 'colonization of the life-world' and human emancipatory interests, and resistance to the 'programmed society' on the basis of clear ideas about what is at stake. In other words, the two sets of theorists are not only agreeing with us that NRMs and NSMs are empirically different but they are also claiming that the movements take their sociological significance from quite different theoretical scenarios. Moreover, each set of theorists tends to be blind to the importance of the other's object of study. NRMs have no significance for the neo-marxists; and NSMs mean nothing to most sociologists of religion (but see Beckford 1989 and Hannigan 1993).

As a result, there are two separate but complementary answers to the question of whether NRMs are NSMs. The answer is clearly 'no' on an empirical 
level. And on a theoretical level the answer must also be 'no' because the two types of movement derive their meaning from incompatible ideas about how present-day societies operate. This is presumably why most sociologists of religion have ignored NSMs and why many neo-marxists are sceptical about the possibility that religion could ever be part of any NSM. Claus Offe, for example, deliberately excludes 'religious sects' from the category of NSMs on the grounds that they allegedly 'do not intend to win the recognition of their specific values and concerns as binding for the wider community' (1985: 827). On the contrary, according to Offe, they supposedly 'retreat to private spaces' (Offe 1987: 70). In other words, they are particularistic and inwardlooking. Alain Touraine would also exclude NRMs from 'the social movement', but his reasons would be different. He would exclude them because they are not self-directing. That is, they follow fixed principles of truth derived from, or revealed through, eternally valid sources and cannot, therefore, be autonomous enough to create a genuinely new form of society. In short, religion has no place in NSMs.

But this is not to say that scholars studying the two different types of movement cannot learn anything from each other's work. It would be helpful for sociologists of religion, for example, to be sensitized to the fact that struggles over the direction of cultural and social change are not confined to religious organizations and that the stakes are broader than personal salvation. On the other hand, the theorists of NSMs could profitably study the literature on NRMs for insights into the social processes of conversion, identity transformation and worldview formation.

\section{The religious quality of new social movements}

We now have to look at questions about the religious quality of some NSMs. This in part should demonstrate the usefulness of an inclusive definition of religion such as that religion has to do with perceptions of 'the felt whole' a la Richardson (1967) or 'ultimate concern' and 'dimension of depth' à la Tillich (1956). The reason for choosing such a broad and inclusive definition is to leave open the possibility that religious qualities might be discovered in places other than those where supernaturalist references are found.

To start with, the signs are not auspicious. Habermas, Offe and Touraine all make a point of distinguishing between (a) movements which turn members in on themselves in a search for some revealed or inherited ideal and (b) movements which open members' eyes to the need to take collective responsibility for the direction of social change. Neo-marxists tend to categorize religion as one of the traditional, communitarian and regressive forces. Certainly, most theorists of NSMs reject notions of transcendence and other-worldliness as sources of motivation, solidarity and integration in late capitalist society. But does this mean that studies of NSMs can have no bearing on religion ? 
One possibility is to argue that NSMs, although quite different from NRMs, nevertheless have something religious about them. The strongest case for the view that there is, in fact, a religious quality in some NSMs has been made by Melucci (1985: 811-12):

Contemporary societies have eliminated from the field of human experience what was not measurable and controllable, what in the traditional world belonged to the dimension of the sacred. The final meaning of existence, questions on what escapes individual experience, feed a new "religious" research or simply a need for connecting the external change to an interior growth... Movements announce to society that something "else" is possible.

Habermas also recognizes that some religious movements may have a potential for defending the integrity of the lifeworld in so far as they 'seek to stem or block' the structures of domination in late capitalist society. Although religious movements do not 'seek to conquer new territory', they can nevertheless be regarded as symptoms of the painful experience of a 'culturally impoverished and multilaterally rationalized' life. Habermas believes that 'the establishment and delimitation of communities, the creation of sub-culturally protected communications groups which further the search for personal and collective identity' (Habermas, 1981: 36) serve only defensive purposes. They do not mount an offensive attack on the differentiated social system. Habermas may, therefore, accept the argument that religious rituals are among the few occasions on which truly 'serious' things can still be said in secular society (Fenn, 1981) but he would undoubtedly question whether religious groups could seriously attack the roots of modern social pathology. Moreover, although Habermas's theory of late capitalism draws heavily on social psychological insights into identity, autonomy and the self, his conclusions are not generally supportive of movements which merely affirm that 'men [sic] have the right to demand assurance of a sense of personal worth from society' (Turner, 1969: 404). Habermas's more radical position is that the emancipatory potential of NSMs lies in their capacity to dictate the future shape of society on the basis of free and rational discussion among all participants: not simply to demand a larger stake in the present system or to model new forms of society on fixed principles of revealed truth.

Yet, it seems that the kind of communicative action that underpins Habermas's project for a rational society is indeed to be found in some religious movements and in certain reformist currents within religious organizations. But, more importantly, many activists in socio-ethical campaigns for human rights, safeguards for the physical environment and an end to warfare, for example, have used religious symbolism to good effect. Habermas (1987) has, himself, acknowledged the crucial role of 'sacred' collective representations in everyday social interaction. My conclusion is therefore that his theory of late capitalism and of the strategies which might 
preserve the benefits of modernity without succumbing to the stultifying effects of a rationalized social system unwittingly provides a justification for seeking changing perceptions of the sacred in NSMs. In particular, discourse in various movements is centred on issues which raise questions about the definition of what should be regarded as irreducibly 'human' and therefore categorically separate from considerations of material or political advantage.

I can clarify this point about the 'spiritual work' which takes place in NSMs most conveniently by analysing some of the ideas and practices which have become characteristic of self-help group (SHGs) in the last few decades. It would take too long to spell out the whole argument here, but I believe that a highly diffuse new social movement has been crystallizing since the 1960 s around notions of identity, stigma, exclusion and empowerment. A kaleidoscopic variety of groups have become active in response to popularized ideas about individual rights to dignity and autonomy coupled with beliefs about the power of collectivities of victims to empower themselves and fight against social exclusion. Many of these SHGs tend to keep out of institutional politics and to cut across conventional lines of social division by age, class, gender or race. They include the whole range of 'Anonymous' groups (from Alcoholics to Overeaters), sundry groups of sufferers from medical conditions, support groups for victims of crime of personal tragedies, and groups compaigning to eradicate stigmas and problematic identities.

The range of SHGs is enormously wide, but they all have certain things in common:

- Perception that their problems are personal, pressing and susceptible of improvement (Smith \& Pillemer 1983)

- Insistence that coping with problems begins with acknowledging that the problems exist.

- Belief that helpers can be helped, and the helped can help others in turn.

- Claim that only sufferers can really understand the problems of other sufferers.

- Conviction that individuals are weak or vulnerable unless they bind together and empower themselves.

- Suspicion of professional experts.

The precise pattern of characteristics and emphases obviously varies from group to group.

In what sense do SHGs display religious qualities? Or how do SHGs do 'spiritual work'? In addition to the purely practical concern with learning to cope better with their problems, participants in SHGs are also exposed to ideas about the causes of these problems and ideas about appropriate responses. The responses invariably involve a re-working of personal and collective identity. In extreme cases, this can involve discovery of 'who I 
really am' or of 'what really matters in my life'. The group offers strategies for putting new-found identity into practice, sometimes as part of a vision of an ideal world from which the key problems would be absent.

Although Robin Gill does not consider SHGs in his recent book on Moral Communities (1992), I have no doubt that they meet most of his definitional criteria. Gills' definition of community is actually borrowed from Habits of the Heart (Bellah et al, 1985: 335)

A community is a group of people who are social interdependent, who participate together in discussions or decision making, and who share certain practices that both define the community and are nurtured by it. Such a community is not quickly formed. It almost always has a history and so is also a community of memory, defined in part by its past and its memory of its past.

It there is an objection that SHGs lack a long history and may therefore fail to qualify as communities, I would reply that the biographical reconstruction which is integral to many SHG ideologies and activities invariably fosters a sense of collective or shared history of suffering, misunderstanding or exploitation. So, I consider SHGs to be communities in a strong sense, lacking only a residential basis. Moreover, they are also moral communities because they inculcate distinctive ideas about the values that they promote (e.g. tolerance, liberation and compassion) and the kind of ideal world that they envisage (without, e.g., stigma, prejudice or discrimination).

But there remains the question of why I detect religious qualities in the spiritual work that SHGs do. After all, they could be moral communities without religious qualities. Indeed, Gill (1992: 65) recognizes that 'the world today abounds with moral communities that owe little to religious truth'. A full answer to the question would take more time and space that I have but would have to take account of several central points.

First, SHGs can radically transform personal identity in a way which bears close resemblance to certain types of religious conversion. A breakthrough is achieved to a more fundamental sense of personhood, with all the implications for a fresh orientation to life. The sense of what is ultimately real is also transformed.

Second, the means to achieving this conversion-like experience in some SHGs is akin to the process of confession or at least testimony. It requires (a) a public confession of inadequacy or dissatisfaction (b) a request for acceptance or forgiveness from the group, and (c) an undertaking to abide by the group's principles for avoiding a relapse.

Third, SHGs offer a kind of salvation or liberation from the shared problem. This is partly a matter of transforming self-identity, partly a matter of defining the community as a specially chosen body, and partly a matter of sharing practical activities which are available only to the initiates. 
Fourth, there is also more than a suggestion of faith in the outlook of SHG participants since the weight of empirical evidence is insufficient on its own to support the claims made about the efficacity of what the groups offer. Much clearly depends on the strength of conviction displayed by members. A form of religious commitment is involved (Rudy \& Greil, 1987).

Finally, SHG participants are sometimes under an obligation to evangelize or proselytize as a condition of retaining their good standing in the community. It is not enough to receive the benefit of membership: members must also minister to others on the principle that the helper needs to be helped.

It seems that SHGs are increasingly performing the tasks which were previously performed by a variety of religious organizations with roots in residential localities. A transfer of religious qualities has taken place. With the exception of Melucci, however, the quasi-marxist theorists of NSMs seem generally unwilling or unable to conceptualize religion in forms other than that of ecclesiastical or sectarian organizations. In this respect they have largely failed to capitalize fully on the advances that Antonio Gramsci made in the understanding of consciousness, ideology and will-formation. This is especially puzzling in view of their professed concern with the centrality of theoretical knowledge, information and cultural values to the late capitalist mode of production. These theorists also appear to be unaware of the findings of sociological research into, for example, privatized, common, popular and fragmented religion. Even more surprising is their apparent ignorance of marxist-inspired currents of liberation theology, theologies of struggle, black theology and feminist theology. It is as if the quasi-marxist understanding of religion were still rooted in the outmoded concepts of church and sect. As a result, there is an inability to re-frame religion in terms which might show that some of it actually runs in channels which feed into many of the NSMs' preoccupations.

\section{Conclusion}

What is needed now is not further wrangling about the conceptual status of NRMs and NSMs. We know enough about the problems of sociological knowledge to realize that our concepts are frequently contested, if not 'essentially contestable'. Instead of confining discussion to matters of conceptualization and definition, then, I suggest that we need to conduct some empirical research into the religious (or, better, 'spiritual') aspects of NSMs. What are we likely to find?

First, if we examine the quality of interpersonal relations in NSMs we shall probably discover that the movements tend to proceed on the basis of interpersonal bonds which come close to Georg Simmel's depiction of religious faith:

The faith which has come to be regarded as the essential, the substance of religion, is first a relation between individuals ... That, in the face of 
reasonable proof to the contrary, we can still retain our faith in an individual is one of the strongest of the ties that bind society. That faith, now, is of a most positive religious character. (Simmel, 1954/55: 8, 9)

There is scope for research into this spiritual quality of social interaction in NSMs and other settings.

Second, although NSMs are sensitive to considerations transcending the mundane world of individual and sectional interests, they do not necessarily refer to the supernatural. Instead, they strain towards a holistic perspective which emphasizes the interconnectedness between, for example, human and non-human, personal and public, physical and mental, national and international, etc.. This amounts to a form of 'transcendent humanism' (Lambert 1989) with strongly spiritual resonances. This phrase was coined by Yves Lambert to designate the kind of ethos which was emerging in a late20th century parish in rural Brittany. His detailed ethnography of the parish showed that the Roman Catholic Church's calendar of holy days and holidays, along with its control over virtually all forms of entertainment, sport and leisure in the village, had gone into decline this century. Lambert summarizes the present-day position as follows:

Nowadays, salvation in the hereafter is no longer the objective of the parishioners. And, in so far as it does remain an objective, it is no longer conceived of as the end of a difficult road, with purgatory on one side and hell on the other, except for a few people. In the eyes of some inhabitants, especially the young, morality, order, and values are based on the commonly accepted necessities of society and not of religion... This Catholicism may be defined as a transcendent humanism, oriented towards achievement in this world while still entertaining the idea of an undramatized afterlife... Either religion contributes to happiness or achievement, or it is useless. (Lambert 1989: 59, 61)

Third, there is a widespread belief in NSMs that the adoption of a holistic perspective can provide access to, or release, new sources of power. NSMs tend to focus these new sources of power on application to practical problems. The underlying optimism is strong in the conviction that the power to solve many problems is available to human beings if they can pool their common resources and if they abandon ways of thinking which are analytic rather than synthetic, dualist rather than monist, divisive rather than constructive. Again, these stipulated conditions for the success of NSMs are as much spiritual as organizational or political.

I am not suggesting that a wave of holism is threatening to engulf all NSMs. My claim is the more modest one that a relatively new sensibility to holistic considerations is working its way into these movements. There is a growing recognition in NSMs of the strengths that can be derived from emphasizing the wholeness of the human person, the interconnectedness of the human/nonhuman environment, the power to be derived from collective consciousness, 
and the essentially global nature of social and natural processes ${ }^{4}$. The thrust is towards a transcendent, but not necessarily supernatural, point of reference.

It matters very little, in my opinion, whether one refers to these three characteristics of NSMs as 'religious' or 'spiritual'. The important point is that they reflect a quality which has usually been overlooked in sociological studies of these movements. They also show that, in spite of all the irreconcilable differences between NRMs and NSMs, the latter still retain a religious or spiritual quality.

4. A good example of this way of thinking is Ynestra King's (1984: 4, 5) desription of what she calls 'ecofeminism':

'We come from the feminist movement, the anti-nuclear movement, the disarmament movement, the holistic health movement... Life on earth and the earth itself are in terrible danger... There are connections between all living things and indeed we women are the fact and flesh of connectedness... Feminism and ecology are where politics comes face to face with biology, and where the spiritual and the political come together... The crisis of this civilization which has led us to the brink of nuclear annihilation is spiritual as much as it is economic.' 


\section{REFERENCES}

Bagguley, P 1992. Social change, the middle class and the emergence of "new social movements": a critical analysis. The Sociological Review 40, 2648.

Barker, EV (ed) 1982. New Religious Movements: a Perspective for Understanding Society. New York: Edwin Mellen.

1989. New Religious Movements. A Practical Introduction. London: HMSO.

Beckford, JA 1985a. The insulation and isolation of the sociology of religion. Sociological Analysis 46, 4, 347-354.

1985b. Cult Controversies. The Societal Response to New Religious Movements, London: Tavistock.

1989a. Religion and Advanced Industrial Society. London: UnwinHyman.

Beckford, JA \& Cole, M 1988. British and American responses to new religious movements. Bulletin of the John Rylands University Library of Manchester 70, 3, 209-224.

Beckford, JA \& Luckmann, T (eds) 1989b. The Changing Face of Religion. London: Sage.

Berger, H \& Hexel, P 1981. Ursachen und Wirkungen gesellschäftlicher Verweigerung junger Menschen unter besonderer Berücksichtigung der "Jugendreligionen". Vienna: European Centre for Social Welfare, Training and Research.

Boggs, C 1986. Social Movements and Political Power: Emerging Forms of Radicalism in the West. Philadelphia: Temple University Press.

Dalton, R \& Kuechler, M (eds) 1990. Challenging the Political Order: New Social and Political Movements in Western Democracies. Cambridge: Polity.

Dyson, A \& Barker, EV (eds) 1988. Sects and New Religious Movements. Special issue of the Bulletin of the John Rylands University Library of Manchester 70, 3, 1-240.

Eder, K 1990. Environmentalism, unpublished paper presented at the XII World Congress of Sociology, Madrid.

Eyerman, R \& Jamison, A 1990. Social Movements: a Cognitive Approach. Cambridge: Polity.

Fenn, RK 1981. Liturgies and Trials. Oxford: Blackwell.

Gill, R 1992. Moral Communities. Exeter: University of Exeter Press. 
Haack, F-W 1979. Jugendreligionen. Ursachen, Trends, Reaktionen. Munich: Claudius Verlag.

Habermas, J 1981. New social movements. Telos 49, 33-37.

1987. The Theory of Communicative Action, Vol. 2. Boston: Beacon Press.

Hannigan, J 1993. New social movement theory and the sociology of religion, in Swatos, WH Jr (ed) A Future for Religion?, 1-18. London: Sage.

Hardin, B 1983. Quelques aspects du phénomène des nouveaux mouvements religieux en République Fédérale d'Allemagne. Social Compass 30, 1, 208-229.

Heelas, P 1991. Western Europe: self-religions, in Sutherland, S \& Clarke, P (eds) The Study of Religion, Traditional and New Religions, 167-73. London: Routledge.

Inglehart, R 1990. Culture Shift in Advanced Industrial Society. Princeton, NJ.: Princeton University Press.

Introvigne, M 1989. Le nuove religioni. Milan: SugarCo.

King, Y 1984. Eco-feminism - where the spiritual and the political come together. Women for Life on Earth, Winter, 4-7.

Lambert, Y 1989. From parish to transcendent humanism in France, in Beckford \& Luckmann (eds), 49-63.

Van der Lans, J \& Derks, F 1983. Les nouvelles religions aux Pays-Bas: contexte, appartenance, réactions. Social Compass 30, 1, 63-83.

Mayer, J-F 1985. Sectes Nouvelles. Paris: Cerf.

1987. Les Sectes. Paris: Cerf.

Melton, J.G 1986. The Encyclopedic Handbook of Cults in America. New York: Garland.

Melucci, A 1985 . The symbolic challenge of contemporary movements. Social Research 52, 4, 789-816. 1989. Nomads of the Present. London: Century Hutchinson.

Offe, C 1985. New social movements: challenging the boundaries of institutional politics. Social Research 52, 4, 817-868.

1987. Changing the boundaries of institutional politics: social movements since the 1960s. 63-105 in Maier, CS (ed) Changing Boundaries of the Political. Cambridge: Cambridge University Press.

Richardson, H 1967. Toward an American Theology. New York: Harper.

Rudy, DR \& Greil, AR 1987. Taking the pledge: the commitment process in Alcoholics Anonymous. Sociological Analysis 20, 1, 45-59. 
Scott, A 1990. Ideology and the New Social Movements. London: UnwinHyman.

Simmel, G 1954/55. A contribution to the sociology of religion. American Journal of Sociolgy 60 (supplement), 1-18 [originally published 1905].

Smith, D \& Pillemer, K 1983. Self-help groups as social movement organizations: structure and social change, in Research in Social Movements, Conflicts and Change, Vol 5, 203-233.

Stark, R 1985. Europe's receptivity to religious movements, in Stark, R (ed) Religious Movements: Genesis, Exodus, Numbers, 301-43. New York: Paragon House.

Tillich, P 1956. Systematic Theology. Chicago: University of Chicago Press, vol 1.

Touraine, A 1985. An introduction to the study of social movements. Social Research 52, 4, 749-787.

Tucker, K 1991. How new are the new social movements? Theory, Culture and Society 8, 2, 75-98.

Turner, RH 1969, The theme of contemporary social movements, British Journal of Sociology 20, 4, 390-405.

Vivien, A 1985. Les Sectes en France: Expression de la Liberté morale ou Facteurs de Manipulations? Paris: La Documentation Française.

Wallis, R 1983. The Elementary Forms of the Religious Life. London: Routledge \& Kegan Paul.

1988 Paradoxes of freedom and regulation: new religious movements in Britain and America. Sociological Analysis 48, 355-371.

Wilson, BR 1990. The Social Dimension of Sectarianism: Sects and New Religious Movements in Contemporary Society. Oxford: Clarendon Press.

Witteveen, T 1984. Overheid en nieuwe religieuze bewegingen. The Hague: Tweede Kamer.

Woodrow, A 1977. Les nouvelles Sectes. Paris: Seuil. 